Article

\title{
Diversity without Pluralism: Religious Landscape in Mainland China
}

\author{
Yongjia Liang \\ Department of Sociology, National University of Singapore, 11 Arts Link, \#04-25, Singapore 117570, Singapore; \\ soclian@nus.edu.sg
}

Received: 3 October 2017; Accepted: 9 January 2018; Published: 12 January 2018

\begin{abstract}
The paper explores religious diversity and pluralism in the religioscape of mainland China with three examples. While religious diversity is de facto practice, "religious pluralism" is not socially recognised, culturally legitimised, or discursively institutionalised. On the one hand, state co-option of religious groups is achieved through particular definition of "religion" without the conceptualisation of pluralism, leaving undefined religious activities to cultural policy or national security measures. On the other hand, practices that might be identified as religious elsewhere does not usually self-identified as such, not to say seek for the right of religious freedom. To explain the absence of articulated/institutionalised "religious pluralism" in China, the paper provides three examples-civil activism against tomb-levelling campaign, "the Society of Disciples" (mentuhui), and a ritual service provider. The paper argues that the religioscape of mainland China is one with de facto religious diversity without the ideology of religious pluralism, because the diverse religious practices do not make a conscious reference to pluralism, remain non-institutional, disinterested in religious freedom, and, most important of all, below the state's radar.
\end{abstract}

Keywords: religious diversity; religious pluralism; China; religioscape

\section{Introduction}

My paper will make use of the distinction between "religious diversity" and "religious pluralism" made by our editors, Enzo Pace and Alberto Da Silva Moreira. They make a useful distinction between the descriptive and the normative by arguing that while "religious diversity" represents the condition in which religious variety is de facto presence, "religious pluralism" suggests an ideology that requests the political authority cultivate and maintain a political landscape in which different religions enjoy equal rights and have equal access to public service. Both "religious diversity" and "religious diversity" are overly debated concepts (Turner 2013), but seldom does one make such a distinction between a descriptive notion and a normative one, which calls for a novel consideration between the old dichotomy of "religion" and "state". In contemporary world, the state often faces the bursting institutionalisation of all kinds of practices claiming religious, and the religious groups are competing among themselves as well as pressing the state for equal, religious status. Political system seems to be legitimate only when "religious diversity" and "religious pluralism" are merging into one. But the question remains: would merging—or, actualisation of "religious pluralism" in the form of "religious diversity" - the only possibility?

I'd like to test the distinction in the Chinese context and question the conditions for such a qualification. I will analyse three examples to illustrate the Chinese religious landscape, or "religioscape" (Hayden and Walker 2013). The first is a civil activism against tomb-levelling campaign in Central China. By constructing a narrative of "freedom of belief", intellectual elites who successfully made the government revert their decision argued for a Confucian version of "religious freedom", in which the legally-recognised religions-Muslim and Christians-had to keep their head low, 
because the Confucian "religious freedom" argument leaves no room for these "foreign religions". The second case analyses the revival of "the Society of Disciples" (mentuhui), which demonstrates how a cracked-down "evil cult" survived not by organising into a religious group, but by schismatic strategy of being small and covert. The third case is the life history of a ritual service provider, whose decades-long practice goes smoothly because of its non-institutional nature. The analysis is based on the primary and secondary data I collected between 2014 and 2016.

While religious diversity is de facto practice, "religious pluralism" in China is not socially recognised, culturally legitimised, or discursively institutionalised. As Robert Weller argues, religious policy in post-1949 China is one in which the state recognises and co-opts five religious and, faced with increasing religious diversity, the state finds that " there is a wide gulf between the very limited religious diversity imagined by the state regulatory framework and the vast growth in actual religious life" (Weller 2014, p. 136). On the one hand, state co-option of religious groups is achieved through defining "religion" without the conceptualisation of pluralism, leaving undefined religious activities to cultural policy or national security measures. On the other hand, practices that has a legal religious status elsewhere might not self-identify as such, not to say seek for the right of religious freedom. In this paper, I argue that the religioscape of mainland China is one with de facto religious diversity without the ideology of religious pluralism, because the diverse religious practices do not make a conscious reference to pluralism, remain non-institutional, disinterested in religious freedom, and, most important of all, below the state's radar. In other words, religious diversity in China produces non-institutionalism, instead of an appeal to religious pluralism.

Most Chinese-at least not anyone I knew of-frequently engage in incense burning, paper-money offering, tomb-kneeing, oracle-seeking, temple-visiting, or horoscope-consulting. However, there are only five religions legally practiced in China. The political and intellectual elites have limited imagination on religious diversity and insist that Chinese are prevalently "non-religious". David Palmer argues that in everyday practices, China is not an exception in terms of religion. In the higher-level modes of organisation, however, we find religious pluralism is denied and religious diversity is severely limited, institutionally, conceptually, and politically (Palmer 2017). In China, practising different religions at one time are the rule rather than exception, and consistency or syncretism is barely needed. After all, according to Viveiros De Castro (2011), inconstancy in belief-believing in different traditions or switching beliefs from time to time-is a western construct, so that Chinese religioscape at the bottom level may not be considered as an exception. This is particularly so to the so-called "popular religion", which is never legitimised because it lacks negotiating elites (Goossaert 2008). The practitioners do not usually have a sense of pan-China community or claim themselves religious.

In theory, Chinese religious diversity and pluralism are consistent. There is legally no religion other than officially recognised ones. Religion is defined as four world religions-Buddhism, Catholicism, Christianity and Islam — plus one Chinese religion, Daoism, a discursive regime post-1949 China inherited from its predecessors based on social Darwinist worldview (Chen 2002). Nationalised in 1912 (Goossaert 2008), the five religions under PR China were co-opted into CCP controlled associations, including the Three-Self Patriotic Movements (TSPM) that represents Catholicism and Protestantism, which in China is prevalently called "Christianity" (jidujiao). Such associations are also in place at the provincial, prefectural and municipal levels under the co-option of the Bureau of (Ethnic and) Religious Affairs at their equivalent levels. CCP thus creates a limited definition of religion in order to reduce its autonomy so that its growth, proselytisation and subversive potential could be carefully monitored. However, there is in fact a great variety of practices falling out of the state system and illegible to the state, practices such as popular religions, redemptive societies (Duara 2003), spiritual cultivations, house-churches, Eastern Orthodox, and Baha'i.

In the legal systems, religious pluralism is not an ideology. "Freedom of religious belief" is. Article 36 of China's Constitution provides "Citizens of the People's Republic of China enjoy freedom of religious belief". However, not only is there no law to specify its deliverance of this constitutional 
right, but also there are negative articles in the Criminal Law against the abuse of religion. Without a law on promulgating "the freedom of religious belief", religious affairs are mostly governed by CCP documents and government regulations, which never mentioned the religious "diversity" or "pluralism". Diversity or pluralism is not something to celebrate. On the contrary, being "religious" implies being wrong. Many studies (Goossaert and Palmer 2011; Goossaert 2008) have demonstrated that "religion", together with "superstition" was introduced around 1900 into China in order to be scapegoated for China's backwardness. Religious groups are not taken as institutions that foster good citizens, but as backward groups consuming "spiritual opium". Since 1992, the official policy requires religious adherents to "adjust to the socialist construction", suggesting that religion was still something left behind in the national development. In a country the state acts as the single most powerful distributors of material and symbolic capitals, religious adherents are strongly regulated and marginalised, both discursively and institutionally.

The reality is a very different picture. Vibrant religious revival is perhaps one of the most "unexpected" phenomena in post-Mao China (Liang 2017). Millions of village temples have been rebuilt. Religious population steadily increases as religious infrastructure expands under governmental or non-governmental sponsorship. Restoration of sacred sites appeals to larger population for community. Officially recognised religions retrieve different regimes of transcendence into diversified localities. Unofficial, translocal, or transnational movements explore their sphere of activities with underground proselytising or with NGO instruments. Popular religion legitimised by cultural renaissance is embraced by astonishingly large population, and commercialised with the state-agents' incentive of generating revenue through translating invented tradition into tourist industry. Ancestor veneration and rituals of almanacs, geomancy, horoscope, and spirit medium are intermingled with new waves of salvationist movements, and body/spiritual/healing techniques. The increasing social/political/economic disparity creates greater anxiety to seek for old ways of oracle-reading, mask-dancing, sutra-chanting, karma-fair hosting, and so on. Lastly, national and global flow of capital, symbols, ideas, and practices also poses unprecedented problem of religious pluralism with increasing mobility.

Despite the strong revival, religious adherents and religious groups seldom, if not never, seek for "religious minority" status or its right. This is particularly so in the case of "house-church", where Christians deliberately or unconsciously keep the state co-opted TSPM church at arm's length. Practitioners of body techniques-breath exercise (qigong), Tantrism, Chinese boxing (taiji), life-nourishment (yangsheng), may not even believe they have anything to do with religion. Nor do the Confucian revivalists, tomb-sweepers, rural temple care-takers, or lineage organisers. I will give three examples to illustrate how de facto religious diversity exists and operates well without a de jure idea of religious pluralism.

\section{The Polyphonic Voices in the Henan Tomb-Levelling Campaign}

The Henan Tomb-levelling Campaign (pingfen yundong) is a provincial government campaign launched in Henan Province in central China, 2012. It aimed at levelling civilian tombs scattered in the predominantly rural province to save arable land. Carried out in several prefectures, the campaign reclaimed a mere $45 \mathrm{~km}^{2}$ land at the expanse of destroying two million tombs. In the Zhoukou Prefecture, the government demanded that all the rural deceased should be cremated without creating new tombs, and all the old deceased buried in tombs should be "levelled" (ping)—-tombs being removed by levelling the soil, rock, or concrete tops. Aware of the possible backlash, some governments hired veterans to use force. Villagers who voluntarily levelled their family members' tombs would be awarded 200 CNY (about 25 EUR). Local officers who failed to complete the quota would be demoted or expelled from civil service. In May 2012, a legislator in the provincial people's congress lost his position for his open condemnation on the policy. While it was said that tombs with offspring sitting in the high-ranking offices would be spared, the tomb of the prefectural governor's mother was once in danger of being levelled by some angry activists. 
The campaign triggered furious protest nationwide. Politicians, official propaganda, intellectuals, liberal press, netizens stood up. Among them, some Confucian scholars finally put the campaign to an end with an open letter. Sixty signed the letter, along with hundreds of media reports and thousands of online articles questioning the campaign's motivation, legitimacy, corruption, inequality, among others, directly influenced the State Council, the nation's supreme executive organ, which ordered to stop "forced levelling of tombs". The Confucianists are mainly university professors in Beijing and Henan, joined by some public intellectuals, media workers, writers, and philosophers. Since scholars and press are seldom able to take organised actions against a provincial policy, their success was celebrated as one of the "Ten Events" of Chinese civil society in 2012.

The open letter deserves our attention because it discusses the sensitive topic of "religious freedom" without invoking an idea of religious pluralism. Scholars condemned tomb-levelling as a "barbaric conduct that seriously violates the freedom of belief, damage Chinese culture, and hurt the feeling of the mass." By "violating the freedom of belief", the Henan provincial and its prefectural governments damaged "the ancestor worship, the most important belief of the Chinese people". The letter quoted some ancient classics about Confucian cosmology "Heaven create things, and ancestors create humans," and goes

From ancient time, Chinese people believe firmly "ancestors have merits and virtues", uphold the idea of "celebrating one's origin by revering Heaven and following the ancestral ways". So they must bury the deceased relatives with proper rites, sealing the tombs and offering sacrifice in four seasons. That's what the classical saying "when alive, serve with rites; when deceased, bury with rites and offer with rites" mean. The Chinese also believe they would join happily with ancestors in another world after death. Descendants thus provide offering for future meetings with them. That's what the classical sayings "offer as if [the ancestors are] present; offer to the gods as if they are present" mean. Belief in the ancestral worship effectively solves the problem of Chinese anxiety about life and death, and gives ephemeral life an eternal meaning. It is indeed the most innocent, widespread, dear, and powerful natural belief of the Chinese. (China Confucian Religion 2012).

As ancestral burial site, tombs are important material abodes of this belief. However, the barbaric "tomb-levelling campaign" in Henan Province ignores the thousands-year-long, most natural and widespread belief of the Chinese people, and seriously violates and deprives of the citizens' rights of freedom of belief. It humiliates men and gods, and shatters law and reason!

The letter goes on by accusing tomb-levelling of "damaging Chinese culture", which is "the tradition of filial piety". It "hurts the feeling of the mass", because even "an ethical Confucian king of the past would protect tombs." In the end, the letter appeals

(1) An immediate ending of tomb-levelling campaign;

(2) The central government's intervention: "[it should] understand that ancestor worship is the basic belief of citizens, and should respect the people's freedom of this belief";

(3) Public action: "the wise public and media should ... maintain the freedom of belief and the custom of the Chinese people, cherish Chinese historical and cultural traditions, and promote the reconstruction of 'cultural China' and 'music-rite China'"1".

The letter plays subtly with the concept of "religion". It resorts to constitutional religious freedom without appeal to "religious pluralism", and ignores religious diversity in Henan. Strikingly, the

1 "Music-rite China" (Liyue Zhongguo) is the ritual institutions of ancient China. The ancient Confucians generally hold that proper music institution manifests the ethics of the rites. 
scholars do so when Confucianism is not a legal religion! While the Constitution states that Chinese citizens enjoy the right of "freedom of religious belief", the letter uses "freedom of belief" by omitting "religion". The scholar-activists sublimate ancestor worship as "most innocent, widespread, dear, and powerful natural belief of the Chinese people", whereas constitutional right for "freedom of religious belief" applies only to state-recognised and co-opted religions-Buddhism, Daoism, Christianity, Catholicism and Islam, where ancestor worship wields no legal status whatsoever. The strong religious tone is therefore relegated into a description of the transcendental world-heaven, dead ancestors, gods, which may all turn indignant against the wrong-doing government along with humans. It is not insignificant when the letter was drafted by two law professors from the elite Tsinghua and Peking universities, who resorted to a legally non-provident "freedom of belief" rather than invoking Land Administration Law or Property Law.

Appealing to the governments to deliver constitutional right was a bold action when it comes to religion. But the action is not about religious pluralism, but religious singularity. In the letter, scholars keep on using the expression "the Chinese people" (zhongguo ren) interchangeably with "citizens", presuming they are followers of Confucian classics. Imagining a community of homogenous people is explicit in the letter signed by many self-identified Confucians who believe Confucianism is an ideal remedy to China's moral decadence. That's why the letter was double-dated in Gregorian calendar as 8 November 2012, as well as the 25 of the Ninth Month, 2653 from the birth of Confucius himself, in the Confucian calendar which was never promulgated. The letter was also Confucian by being officially released by four Confucian websites: China Confucian Religion, Confucian China, Confucius 2000, and China Mainstream Culture. It creates a regime of authenticity, by which all Chinese people in the Henan Province are Confucians who venerate ancestral tombs.

Here comes the problem: Confucianism is not just a legally non-recognised religion, but also not a religion shared by all Henan people. Far from it, Henan is one of the few provinces densely populated by Muslims as well as Christians, both of whose religions are legally recognised. The prefectures involving in mass-destruction of tombs-Zhoukou and Nanyang-are heavily populated by Christians and Muslims, though real statistics are never collected. During the campaign, the policy document explicitly stated "Muslims tombs are exempted" for the fear of likely protest. But the exemption is not based on the religious minority status, but on the "particular custom" of the Hui ethnicity, though other ethnicities who live in the province did not enjoy this positive discrimination policy. More interestingly, it seems Muslims are not considered as citizens when the governments vowed to let every new rural dead cremated. Muslim population also remain largely silent. They seldom produced an opinion on the polyphonic controversy on the campaign, except for a few cut-and-paste articles appearing on the website China Muslim Online.

While Muslim tombs were not destroyed, Christians were. Videos on different websites show that some tombs with crosses on the top got levelled. Two death directly caused by the campaign were also Christians. In Zhoukou Prefecture alone, Christianity, mostly "house church", have spread in almost every single township. Many Christian tombs might have been levelled. The "China rite controversy" over funeral rites is a long story (Li 1998; Huang 2012), but to cut it short, funeral differences are the major issue. Generally, Chinese Christians respect the deceased but refuse to participate in "idolatry" funeral rites. Therefore, when a Christian dies, the funeral is usually marked with solemnity, soberness, and simplicity, lacking ritual technologies (Lim 2013). The Christian tombs, not a site of worship, are there for memorial. In other words, Christians in Henan cherish tombs, too, but the reasons are different from what the Confucian letter outlined.

Some Christians, however, supported the campaign. A house church leader stated that Christians deemed the campaign "civilised" (wenming): "We believe there is only bones in the tombs, not the souls. Please start the campaign with our tombs." The statement is often quoted by the state authority, who often denied the existence of the house church, because of their refusal to join the state co-opted TSPM Church. Second, many house churches hold rather radical theology that despises physical representations such as bones and tombs. 
House-church statement might add an alternative view to the campaign, but what they met was condemnation from some local scholars. In a few articles published by Hunan Institute for Rural Studies, the message by the house church leader was interpreted as a threat to the state. "In this campaign to exterminate the Han's tombs, Christians for the first time launch their attack and debut in the Chinese political stage. Levelling tombs will definitely help Christian proselytisation in this province" (Ouyang 2012). The article continues to accuse Christianity of "controlling many local governments", and the campaign therefore might be a Christian plot to destroy Chinese culture and belief. Some also accuse Christianity in Zhoukou of "degrading into" a sect as radical as the Taiping Rebellion which brought about tremendous disaster to China in the 1860s.

The religious diversity in Henan province is an important context for the tomb-levelling campaign to unfold. A rather odd campaign is at the once totalising, hegemonic, and divergent. Totalising, because the government exerted arrogant power on the deathscape of all peasants. Hegemonic, because the social activism against the policy claimed a fictive community of Chinese people who believe in Confucianism, and thus marginalises the religious minorities of Muslims and Christians. Divergent, because the campaign triggers alternative voices from the house-churches who paradoxically support the policy, but, face the accusations of destroying Chinese culture.

The polyphonic voices demonstrate de facto religious diversity in Central China, but none of the voicing parties resorted to the value of religious pluralism that implies equal rights, egalitarianism, or a polytheistic pantheon.

\section{The Schismatic Strategy of "the Society of Disciples"}

If the polyphonic voices in the tomb-levelling campaign suggests a diversity without pluralism in the public sphere, "Society of Disciples" tells how religious diversity is possible when a declared "evil cult" adopts its schismatic strategy. "The Society of Disciples" (SD, or Mentuhui) was a Christian-inspired religious movement popular in rural north and west China, founded by Ji Sanbo (1939-1997), a poor, barely literate peasant in northwest China's Shaanxi Province. Baptised in 1977 after traumatically losing his sons, he set up his house church and began itinerant evangelism. Exposed briefly in 1982 to another Christian-inspired movement-the Shouters (huhan pai), he wrote a pamphlet about the approaching apocalypse based on his knowledge of the Bible. In 1989, after his followers reached to several hundreds, he declared himself the Second Coming of Jesus Christ, incarnated to mark the "Third Redemption" (the other two being Noah's Ark and the First Coming of Jesus). Like what was said in the New Testament, he ordained 12 disciples, which gave the name of the cult, though Ji himself insisted he represented the true Christianity.

The apocalyptic theology often forces the adherents to retreat from livelihood activities. They have devote themselves to fasting, praying and proselytisation before the world ends, which was said to be 1 July 1997, and then postponed once and again. Fasting may last as long as 32 days, and a good devotee may only consume $100 \mathrm{~g}$ of grains. The adherents are required to practice anti-idolatry, filial piety, prudence, and chastity, but not reading the Bible. After all, most adherents are barely able to read anything.

Patriarch Ji was said to have performed different miracles, mainly about healing different kinds of handicaps like Jesus. One day, when a crippled woman offered him some water, Ji prayed and a beam of light came through and healed her. In another occasion, Ji prayed in a funeral gathering and summoned the dead soul back to life. His grain has unlimited supply. He walked above a river. Praying is miraculous: when Ji prays, he sees heaven, hell, the entire globe; he sees through human; he hears the voice of God.

At its inception, the Society was aware of the possible crackdown, which finally befell in 1995. That year, the Society had grown from 30 thousand in several counties of one province to over 500 thousand in 681 counties of 15 provinces. Ji was arrested in 1992 on charge of "organising evil cults" (zuzhi xiejiao zui). He was released in July 1997, but five months later, he was killed in a car accident. Meanwhile, the police located, infiltrated, monitored, raided and disbanded most of the congregations, 
and arrested and jailed top leaders. They did so because the Society was never a "religion", but an "evil cult" (xiejiao), legitimately subjected to crackdown. According to Article 300 of the China's Criminal Law, "Whoever organizes or uses superstitious sects or secret societies or evil cult, or uses feudal superstition to undermine enforcement of the state's laws or administrative regulations shall be sentenced to fixed-term imprisonment of not less than three years and not more than seven years. If the circumstances are especially serious, the offender shall be sentenced to fixed-term imprisonment of not less than seven years."

However, this is far from the end of the story. The Society survived, continued and grew fast. Each year, there are more county police departments releasing reports about their campaigns against the Society of Disciples, suggesting it has been growing. By the time my empirical study ends in 2015, it has spread to almost all corners of China. However, due to security measures, the number of the Society is kept secret, and of course beyond counting. Then, why does the state's heavy-handed crackdown didn't work? Why could the Society grow under the nose of one of strongest state machines in the world?

I argue that the Society survives and grows because of its adept strategy of schism. The strategy is to avoid institutionalisation simply because institutionalisation means legibility to the state who would inevitably crackdown the organisation. On the other hand, being schismatic immensely reduces the possibility of entire destruction.

Schism is achieved by a mechanism similar to the "pyramid sale", that is, creating a strong proselytising incentive by putting the newly initiated into serious debt, and create a strong master-disciple relation rather than a multi-layer hierarchy. Once a new member is initiated, he/she is required to give most of the properties to his/her initiator, and destroy the rest-slaughtering the domestic animals and deserting the farms. He will have to fulfil high proselytising quota in a limited period, such as converting 20 people (called "fruits") in a month, in order to receive reward to meet his everyday need. If he is very successful, he will be promoted to higher level and enjoy more benefits. But if he fails, magical punishment like terminal disease, accident, or misfortune will come down from above. Therefore, proselytisation is rather frenzy or even die-hard. However, the hierarchy in the real world are mostly limited to initiators and their disciples because of that debt.

Since the state crackdown, the Society's leadership structure has shifted from centralised hierarchy to a schismatic one, too. Under Ji Sanbao's leadership, the structure consisted of seven layers with him on the top. Since 1995, the formal structure was less and less relevant. A lower group head was not necessarily able to tell the name of his superiors, and often operated independently. Ji's successor, Patriarch $\mathrm{Xu}$, was much less influential to the point that many members didn't know he died of cancer in 2001. From my fieldwork in southwest China's Sichuan Province, I found no one knows the name of the third patriarch Chen Shirong, who has been in jail for years. In other words, proselytisation operates without a formal hierarchy, not to say a command chain.

Being schismatic is to be covert. Since the crackdown, the Society began to adopt alternative names for their cult. Instead of "Society of Disciples", they use "Christ, The Third Redemption" (sanshu jidu), "Narrow Door in the Wild" (kuangye zhaimen), "Two liang of grains" (erliang liang), or other less well-known names. When arrested and interrogated, many appear to be unable to identify their initiators, since the latter usually call themselves "executives" rather than disclosing their real names and addresses. They never contact his disciples through cell phone (Xie 2010).

To hide their identities to the outsiders or even the initiated is a common practice. Most conversions seemed to be achieved through spiritual healing. According to Liu (2013), in an Inner Mongolian village, a man came and preached about praying in the name of "Ji, the Third Redemption" to heal all kinds of sickness, because all physical problems are caused by sin. He declared that "heaven is a big hospital", and "It's a waste of money to try medication". However, he did this through very covert and guerrilla strategies—called "covert propagation, covert believing, and covert praying". The most important rule is to conceal the preacher's identity to a stranger until he's converted. For example, when a visitor knocks at the door during preaching, he and his potential 
converts would immediately change the subject, and the converts will introduce him as a distant relative living far away. Incidental disclose of the Society's identity will lead to secret punishment.

A villager named Wang described his experience with the Society of Disciples (Liu 2013). One day, a stranger knocked at his door, saying he learned about Mr Wang's illness from a distant relative. He told the Wangs that he is a member from the "Christ, the Third Redemption", sending a message about Lord Ji Sanbao, who is able to "exorcise the evil spirits and heal". He then gave a few testimonies about spiritual healing through praying without medicine. Wang and his wife didn't oppose the idea and decided to try.

The stranger came the next day, asking being addressed as "executive" (zhishi) and giving the Wangs several pamphlets. In the following month, the executive came every day, making sure that the Wangs studied the pamphlets by kneeing down before two white candles symbolising Patriarch Ji. A 70-year-old woman volunteered to join the group, who turned out to be an undercover adherent. The old woman often brought expansive food to the executive, making the Wangs under the pressure of offering expansive gifts too. About twenty days later, Mr Wang did not feel any better and questioned the executive, who relied, "it's not long enough to make Lord feel your devotion". According to the Wangs,

“One day, the executive brought two others to 'help' and convey the message from Lord. They put me and my wife in the middle and started their never-ending sermon. I got impatient, asking them to leave and telling them I won't believe your thing. I warned them, 'if you came to my door again, you'll get nothing but my fist.' The two strangers never show up." (Liu 2013, p. 35).

However, the executive himself soon came around with two other men who claimed to be the 'messengers' conveying 'God's edict' on behalf of Lord Ji. The Wangs were made knee down again to humbly receive the edict. The new strangers showed two pieces of papers to be burned after reading for the sake of efficacy. Since the Wangs were illiterate, they were told to receive the edicts separately. It took an hour for the sick couple to listen to the edict by kneeing. Again, Mr Wang protested but the executive didn't stop. Wang got angry: "I physically kicked them out." No one showed up ever since.

The Society of Disciple shows how a cracked-down religious movement operates in China. The Patriarch started his preaching by a radical change of the Bible, and ascended to a paramount, syncretic supremacy. Claiming the sole access to the transcendental world, the patriarch started his sect by deliberately claiming a religious movement that incorporated popular values of filial piety and chastity. The state suppressed with reasons similar to the imperial court: it's the sect deliberately challenged to the political and economic order, but particularly, the cosmological order.

The schismatic strategy of the Society of Disciples demonstrates how religious diversity is already there without the ideology of religious pluralism. The strategy is the direct result of the state's non-pluralistic policy. The state's intolerance has good reasons-any religion challenging the secular order with transcendental claims should face crackdown. When millions of adherents were well-organised around the cult of a patriarch, the subversive stake became too high to survive under the state's nose. Schism changed the cult from a centralised organisation into an acephalous one with P2P relations as the major form of association, thus making it possible to operate under the state's radar. The strategy proves effective by saving the cult and making it grow. By adding yet another "nova religio" to the Chinese landscape of religious diversity, the Society of Disciples is an example of survival without the ideology of religious pluralism.

\section{Amorphous Religion: A Ritual Service Provider}

The third case is the life history of a ritual service provider, whose decades-long practice continues because of its non-institutional nature. A poor woman born and raised in a village at the Liangping County, Chongqing Municipality, Yin never travelled beyond her hometown. Nor does She ever knew there are thousands of persons like her providing ritual service to millions of peasants in almost every 
corner of rural China. They probably form the largest religion in China, if not in the world, a religion alternative to the five major religions. But they don't have a sense of community. Compared with Yin, the argument that there is one Chinese religion is a top-down perspective (Freedman 1979). Instead, they operate as individuals. I argue it is this amorphousness that makes the stellar addition to the pantheon of religiosity in contemporary China, and again, another evidence of religious diversity without the idea of pluralism.

According to Tang Huan (Tang 2014), Yin was born in 1954 into a poor rural family. Without any formal education, she leads an ordinary rural life in an era of material scarcity, political turmoil, and hard working. She never thought she would become a "spiritual medium" (lingmei)—an involuntarily manifestation of some certain deities-until she underwent a series of strange experiences. In that part of rural China, only woman was eligible to becoming a medium, by kinship—if her or her husband's family had one, or by possession-if she was often "insane" (feng). She would seek for diagnosis from a medium, who was likely to become her potential master and teach her skills. For Yin, she began her spiritual journey when encountering a few bad lucks-collapse of her house and her health, haunted by her deceased mother-in-law, and sudden unconscious possessions by unknown spirits. She sought for help from a Madam Chen, a spiritual medium, who installed a patron god (zuotai shen, "hall-sitting god") in her house for her to "attend to" (gongfeng). But she was possessed once and again by a number of deities who asked her to "save mundane lives", a sign of her readiness for mediumship. It was a hard decision because being a "spiritual medium" was despised in the village, and its role was not to make a career but to "help others". However, repeated possession left her without choice but to study with Chen on the different skills of providing ritual service, mainly about different rituals of exorcism, purification, healing. It was like a response to a call from gods, and her "conversion" looked like involuntary reception of a charismatic power.

Being Madam Chen's disciple, Yin was initiated into a master-apprentice clinch that constituted a sort of vocational community. However, such a community was fluid. First, there was no hegemonic discourse in regard to mediumship knowledge. Individual interpretations over personal dreams, signs, mishaps, and illness were common among fellow mediums. Mediums choose their own remedies without consultation with others. It's like a private practicing doctor answering to called requests to solve a customer's problem. Secondly, there were limited ways for curing a symptom but the skills of doing it were quite easy to learn. For example, when someone was "offending" a god, the medium would "send a flower vase" to the god in question by charging the customer a few cash for purchasing simple paper ingots to be burned in her own house. She made a profit by saving several cents for each service, barely making a living. The skills are so easy that mastering them does not qualify a medium. Extraordinary experience does. Thirdly, the medium community is not an institutionalised one. Not only the state is unaware of this illegible community (and, if it does, it's more likely that the state would dismiss it as harmless superstition), but the spiritual mediums never form a community. There is little room for an institutionalisation process based on the interaction between power and knowledge.

There is a vague sense of community, however. The spiritual mediums in rural Liangping County would identify themselves as "Buddhists", who had vowed to observe the "five abstentions" (wujie): killing, stealing, adultery, deception, and alcohol. At the 23 of each month, they also gather at a local park to exchange ideas and experiences, and gossip about life. They observe Buddhist holidays at the local temple. Each will donate a little cash to the temple to ensure that her gift of communicating with different gods continue to be effective. At one of these occasions, 19 June, the ordination day of Avalokitesvara, is important. The mediums pool some money to hire a monk to "open a shrine", in which each individual medium would seal a pack of paper ingots with her name and the amount of donation for the monk to send it to the goddess. This is most important occasion to renew one's lingxing, or magical power. If a medium spontaneously sings odes to the goddess in the following days, that would be the most wonderful sign of being heard and blessed with renewed power. All these 
are not mandatory, but a free association in the true sense of the term. Above this loosely associated community, there is no further connections (Tang 2014).

Most of time, Yin practices her mediumship alone. She looks after her patron god at home, and, when requested, she treats different problems for her clients. According to her, most of the problems are caused by improper contact between gods and laypersons, and only a medium can separate them apart. A lay person does not know how to contact gods, and the latter don't know the specific demand of the former. Her role is to ensure proper communications.

Yin never got questioned by a police officer, a village head, or any other state agent. Nor does she ever worry about her practice. To her, it's a vocation and the only way to make a living. When she learned the mediumship skills in late 1990s, Chinese state has long relaxed its campaign against superstition, but tightened its control on translocal, subversive religious movements such as the Falungong. Yin's practice remains within the doorstep of her or her clients. She never travel beyond $30 \mathrm{~km}$, and her mediumship community has no formal organisation or any power over her. She is a classic religious minority, but she never feels it. Nor does she think being minority is ever relevant to her life. She provides ritual service, like a self-employed peddler, and she is doing well not because of being religious minority, but because of her religion's amorphous nature. In other words, her religious practice diversifies China's religiosity, without being recoginised under the ideology of religious pluralism.

\section{Conclusions}

Analytically, it is important to distinguish between the empirical conditions of religious diversity and the normative vision of pluralism. For the former, religious heterogeneity is a vibrant reality in contemporary China and, I believe, everywhere. For the latter, Chinese formal political system hopes to reduces this reality into just five normative religions. It is unfair to say China is an anti-religion, atheistic state, since there is a certain mode of pluralism could be called "hierarchical plurality" (Liang 2014). However, the pluralism is highly coordinated, deeply ideologised, and extremely rigid. Peletz (2009, p. 7) rightly defines pluralism as diversity which is accorded legitimacy. Yet, as Formichi (2014, p. 2) points out, "this approach leaves untouched the issue of where the legitimacy emerges from", and there are the cases that "point to the interplay of societal behaviour and government policies as a crucial factor in determining the outcome" (ibid., p. 2). In a sense, religious pluralism is normative in double ways: a government discourse and a pressing voice from the intellectual.

The three cases presented in this paper intend to show how religious diversity operates without an accommodating ideology of religious pluralism. I emphasize that religious pluralism is barely an ideology not just at the disposal of the state apparatus-constitution and government, but also on the part of the religious adherents themselves. The scholar-activists, the house-church Christians, the rural constructionists, the disciples of Patriarch Ji, the ritual service provider, none of them resorts to an idea of religious pluralism—the idea of according legitimacy to alternative beliefs. Of course, the interesting discrepancy between the reality of religious diversity and the absence of religious pluralism demonstrates an anomaly with one of the most vibrant religious landscapes in the world. However, isn't it also demonstrate the anomaly lies somewhere else?

Acknowledgments: This article is one of the outputs of the project, 'Religious Activities in the Ethnic Area of China' (No. 14BSH091), supported by the Chinese National Social Science Fund.

Conflicts of Interest: The author declares no conflict of interest.

\section{References}

Chen, Xi-Yuan. 2002. Zongjiao: Yige Jindai Zhongguo Wenhuashi Shang de Guanjianci (zongjiao/religion: A keyword in the cultural history of modern China). Xinshixue 4: 37-66. 
China Confucian Religion. 2012. “Guanyu Liji Tingzhi ‘Pingfen Yundong' de Jinji Huyushu” (Urgent Appeal Letter on Immediate Stop of the 'Tomb-Levelling Campaign). Available online: http:/ / www.chinarujiao. net/p_info.asp?PID=16077 (accessed on 2 April 2015).

De Castro, Eduardo Viveiros. 2011. The Inconstancy of the Indian Soul: The Encounter of Catholics and Cannibals in Sixteenth-Century Brazil. Chicago: Prickly Paradigm Press.

Duara, Prasenjit. 2003. Sovereignty and Authenticity Mancbukuo and the East Asian Modern. New York: Rowan \& Littlefield Publishers.

Formichi, Chiara. 2014. Religious pluralism, state and society in Asia. In Religious Pluralism, State and Society in Asia. New York: Routledge, pp. 1-10.

Freedman, Maurice. 1979. The Study of Chinese Society. Edited by William Skinner. Stanford: Stanford University Press.

Goossaert, Vincent. 2008. Republican Church Engineering. The National Religious Associations in 1912 China. In Chinese Religiosities: Afflictions of Modernity and State Formation. Edited by Mayfair Mei-hui Yang. Berkeley: University of California Press, pp. 209-32.

Goossaert, Vincent, and David Palmer. 2011. The Religious Question in Modern China. Chicago: University of Chicago Press.

Hayden, Robert, and Timothy D. Walker. 2013. Intersecting Religioscapes: A Comparative Approach to Trajectories of Change, Scale, and Competitive Sharing of Religious Spaces. Journal of the American Academy of Religion 81: 399-426. [CrossRef]

Huang, Jiaofeng. 2012. Zheyang de Rujia bu Liqima?-Yetan Jidujiao de Jizu Wenti (Is This Brand of Confucianism Wired?-My Idea on Christians View on Ancestor Worship). Available online: http:/ /www.21ccom.net/ articles/gsbh/article_2013110394694.html (accessed on 20 April 2015).

Li, Tiangang. 1998. Zhongguo Liyi Zhizheng (China Rite Controversy). Beijing: Zhonghua Shuju.

Liang, Yongjia. 2014. Hierarchical plurality: State, religion and pluralism in southwest China. In Religious Pluralism, State and Society in Asia. Edited by Chiara Formichi. New York: Routledge, pp. 51-70.

Liang, Yongjia. 2017. Religious revival in rural China and the fate of 'religion' in China. Chinese Journal of Sociology 3: 268-90. [CrossRef]

Lim, Francis Khek Gee, ed. 2013. Christianity in Contemporary China: Socio-Cultural Perspectives. New York: Routledge.

Liu, Fei. 2013. Nongcun 'Sangao' Qunti de Jiuyi Xingwei Jiqi Xianshi Kunjing (Medical Behaviour and Practical Difficulties of Rural "San Gao" Group. Master's Thesis, China Agricultural University, Beijing, China.

Ouyang, Lan. 2012. Pingfen Yundong Zhuli Wailai Wenhua Gongcheng Luedi (Tomb-Levelling Campaign Assists Foreign Cultural Invasion). Available online: http:/ /www.zgxcfx.com/Article/52443.html (accessed on 12 April 2015).

Palmer, David. 2017. Is Chinese (Lack of) Religion Exceptional? In Religious Cognition in China. New Approaches to the Scientific Study of Religion. Edited by Ryan G. Hornbeck, Justin L. Barrett and Madeleine Kan. Berlin and Heidelberg: Springer, pp. 17-34.

Peletz, Michael. 2009. Gender Pluralism: Southeast Asia Since Early Modern Times. New York: Routledge.

Tang, Huan. 2014. Yige Lingmei de Xingcheng Jizhi (Mechanism of Becoming a Mediator). Bachelor's Thesis, China Agricultural University, Beijing, China.

Turner, Bryan S. 2013. The Religious and the Political: A Comparative Sociology of Religion. Cambridge: Cambridge University Press.

Weller, Robert. 2014. The Politics of Increasing Religious Diversity in China. Daedalus 143: 135-44. [CrossRef] Xie, Ying. 2010. Black Religious Market Turns Grey (Huishihua de Heishi Zongjiao). Kaifang Shidai 5: 134-45.

(C) 2018 by the author. Licensee MDPI, Basel, Switzerland. This article is an open access article distributed under the terms and conditions of the Creative Commons Attribution (CC BY) license (http:/ / creativecommons.org/licenses/by/4.0/). 